- and Children's Hospital in Singapore, understanding the fetal immune system was important for his goal of developing stemcell treatments and gene therapies for genetic disorders in developing fetuses. Chan and his colleagues wanted to know whether there was a developmental stage at which such treatments could be given without the risk of the therapies themselves being attacked by the immune system.

To do this, Chan teamed up with immunologist Florent Ginhoux at the Agency for Science, Technology and Research in Singapore to study dendritic cells, immune cells that break down foreign material and present fragments of it to other immune cells called T cells. Some T cells are then activated to target the foreign material for destruction.

The team found that human fetuses have functional dendritic cells by 13 weeks of gestation. But although the cells behave much like the adult versions, their response to foreign human proteins differs: rather than mark the foreign material for annihilation, fetal dendritic cells are more likely to activate a special category of $\mathrm{T}$ cell called regulatory T cells, which suppress immune responses.

This could reflect a need to avoid a catastrophic immune response against a mother's cells. "You don't want too much immune response in a developing fetus," says Ginhoux. "It is very dangerous - this is a critical point in development."

Previous studies had found specialized immune cells - including T cells and natural killer cells - in fetuses as young as nine weeks, says Ginhoux.

But the dendritic-cell findings are particularly important because these cells orchestrate immune responses, says Michaelsson. Without them, he says, the body can't target specific foreign material for destruction.

The results highlight the fact that the fetal immune system is not merely an immature, less-active version of its adult counterpart, but one that has its own distinct function, says transplant immunologist William Burlingham at the University of Wisconsin in Madison.

Burlingham's laboratory had been studying fetal immune responses as a means of finding ways to help organ-transplant recipients tolerate their new organs without relying on immunosuppressive drugs. But a political uproar in the United States during the past few years over research using fetal tissue has made him shift much of his work to studying the newborn immune system, which tends to act more like the adult system.

The Nature study highlights how this shift could come at a price for many areas of research, says McCune. "It's important for us to understand the function of the human fetal immune system so that we can treat fetuses that are not doing well," he says. "And the analysis of adult and newborn cells is, as we now know, irrelevant. The fetal immune system is different." -

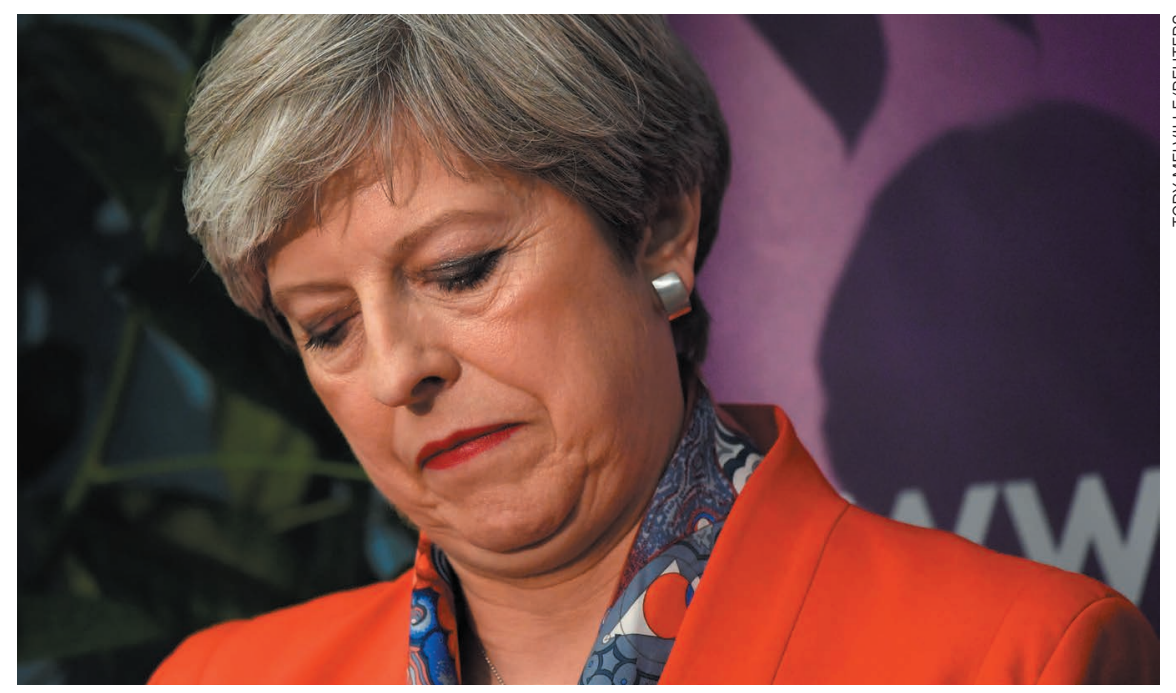

Theresa May's plan to increase her party's majority ahead of Brexit negotiations has backfired.

POLITICS

UK election raises
hope of soft Brexit

Scientists hope for benefits in shock result.

\section{BY ELIZABETH GIBNEY}

$\mathrm{T}$ The UK general election on 8 June has thrown the country's politics into disarray - but scientists trying to divine meaning from the chaos hope that the result will ultimately benefit their nation's research ties with the European Union.

The Conservative government had called the election in an effort to stretch its slim majority, which would have given it a firmer mandate to negotiate Brexit, the United Kingdom's split from the EU. The party, under the leadership of Theresa May, was aiming for a 'hard' Brexit - placing priorities on ending the free movement of EU citizens to the United Kingdom, cutting immigration and taking the country out of the EU's single market. That stance alarmed scientists: it seemed likely also to cut the United Kingdom out of EU research programmes and dent the easy movement of scientists to and from the EU.

But the party actually lost seats - ending up eight short of an overall majority, although still the largest single bloc in the British parliament. After the result, which is termed a 'hung' parliament because no party has an outright majority, May said that she would form a government anyway, relying on the support of Northern Ireland's Democratic Unionist

\title{
UNEASY PARTNERS
}

\section{The Democratic Unionist Party's controversial views}

The Conservative Party is relying on an informal agreement with Northern Ireland's Democratic Unionist Party (DUP) to form the next government - which has put a spotlight on some DUP views. The party has a policy to block women's access to abortion; a Member of Parliament who has called the Paris climate pact "totally flawed and pointless"; and a sizeable minority membership who think that creationism should be taught in science classes. But researchers needn't worry that such stances will affect UK laws: other politicians would veto them, says Kieron Flanagan, a science-policy researcher at Alliance Manchester Business School, UK. The DUP does advocate for a softer Brexit, however: it wants to maintain an open border with the Republic of Ireland after Britain leaves the European Union. 
Party, a relatively minor player in UK politics (see 'Uneasy partners'). Her cabinet remains largely the same: Greg Clark is still in charge of the Department for Business, Energy and Industrial Strategy - which has ultimate responsibility for research - and Jo Johnson is still science minister. The proBrexit politician Michael Gove has been appointed as environment minister.

Although the situation remains uncertain, the result suggests that the government has lost its mandate for the strict Brexit deal for which May had been aiming, says Paul Nightingale, deputy director of the Science Policy Research Unit at the University of Sussex in Brighton, UK. The result "makes it more likely that the UK will have a softer Brexit and will stay within EU science programmes", says Nightingale, who was speaking in a personal capacity.

Any softening of the United Kingdom's position on Brexit is "obviously good for our chances of staying in EU funding programmes", agrees Kieron Flanagan, a science-policy researcher at Alliance Manchester Business School, UK. "Planning to ameliorate the effects of Brexit on science and research should be the number one goal," he says.

"The optimist in me hopes that the hung parliament we seem to have at this stage might end in a rethink on Brexit, perhaps a delay," adds Anne Glover, a biologist at the University of Aberdeen, UK, who was formerly the European Commission's chief scientific adviser.

\section{'STILL IN A MESS'}

Senior Conservatives say that the result could weaken the United Kingdom's hand in negotiations with the EU, which were set to begin on 19 June but may now be delayed. And although May will remain Britain's prime minister for now, her long-term position as leader could also be in doubt. "May will limp along, but, politically, she is toast," says Nightingale. If she does ultimately go, then the Conservative government's direction might shift under new leadership.

Ahead of the election, all three main national parties had pledged to raise funding for science, an unusual consensus that reflects the difficulties UK research could face as a consequence of Brexit. These funding commitments are welcome, researchers say, but the election result still leaves a cloud of Brexit uncertainty over science. "We had an evidence-free EU referendum, and now we have a negotiating party who, by their own admission, think their negotiating position has been weakened," says Glover. "Not much cause for celebration - the future of research in the UK is still in a mess." -

Additional reporting by Laura Castells Navarro.

\section{POLITICS}

\section{US space-policy council resurrected}

\section{Group will oversee civilian and military space activities.}

\section{BY ALEXANDRA WITZE}

$\mathrm{T}$ he United States will revive the longdormant National Space Council, a group meant to coordinate space policy among government agencies and departments. Vice-president Mike Pence, who will chair the council, announced its reinstatement on 7 June at NASA's Johnson Space Center in Houston, Texas.

First constituted in 1958, the space council - or some iteration of it - has been active sporadically, most recently between 1989 and 1993. Since then, space policy has been run mainly from the White House Office of Science and Technology Policy (OSTP) and NASA.

Restarting the council will better coordinate the country's space endeavours, Pence said. "President Trump recognizes America needs a coherent and cohesive approach," he added. The council "will make sure America never again loses our lead in space exploration, innovation and technology".

In theory, the National Space Council oversees US space policy at NASA and defence, intelligence and commerce agencies. In practice, however, it sometimes has had little power to change entrenched practices among various agencies - particularly in military affairs.

"As long as Trump has Pence's back, and Pence decides to place a lot of emphasis on his role as chair of the space council, it has a potential to make a difference," says John Logsdon, a space-policy expert at George Washington University (GWU) in Washington DC. In its 1989-93 incarnation, the council played a major part in developing then-president George H. W. Bush's plans to send astronauts to the Moon and Mars. It also worked on space issues with Russia after the collapse of the Soviet Union.

The reinstated council will be successful if it coordinates the government's work with that of the burgeoning commercial space industry, says Logsdon. Private companies currently have contracts with NASA to ferry cargo up and down to the International Space Station, and will soon transport US astronauts. A council could strengthen commercial space connections outside NASA.

The council could also better coordinate diplomatic relationships with other space-faring countries, Logsdon says. "There's a full plate there to be eaten," he says.

Whether US space agencies will get adequate funding to carry out such efforts is unclear. Speaking at Johnson Space Center, Pence said that "NASA will have the resources and supports you need to continue to make history". But the White House has proposed trimming the agency's US\$19.7-billion budget by roughly $3 \%$ for the next fiscal year, to $\$ 19.1$ billion - a relatively moderate reduction compared with the double-digit cuts outlined for other science agencies.

Scott Pace, the head of the Space Policy Institute at GWU, is widely expected to be named as head of the space council's staff. Pace's extensive government experience includes roles at NASA and the OSTP during the administration of George W. Bush.

\section{WAITING ON THE WHITE HOUSE}

Trump has said little about NASA other than to reiterate themes of US leadership in space, and to joke about recycled urine during a conversation in April with Peggy Whitson, then the commander of the International Space Station. Pence hinted in March that the council would be resurrected. Space-policy advisors to the Trump“There's a Pence campaign argued fullplate for its reinstatement last there to be eaten." October, before Trump won the presidency.

The new administration has yet to put its stamp on the agency. Trump has not named a new NASA chief. Although the agency continues to develop a heavy-lift rocket and crew capsule to take astronauts to deep space, the 'Journey to Mars' that was pushed during the presidency of Barack Obama is no longer ascendant. It remains unclear whether Trump's White House will work to send astronauts back to the Moon, on to Mars or to some other deepspace destination.

Pence made the space-council announcement at an event to introduce NASA's 12 new astronaut candidates. They include scientists Jessica Watkins, a geologist at the California Institute of Technology in Pasadena who works on Mars rovers, and Zena Cardman, a geobiologist at Pennsylvania State University in University Park.. 